personality: Methodical manual]. Kyiv: Talkom. 208 [in Ukrainian].

Rybalka, V. V., Samodryn, A. P. \& Morhun, V. F. (2019). Psykhopedahohichni ekspedytsii shliakhamy demokratyzatsii zhyttia osobystosti, osvity ta hromadianskoho suspilstva: Metodychnyi posibnyk [Psychopedagogical expeditions to democratize the life of the individual, education and civil society: A guide]. Kyiv: Talkom. 280 [in Ukrainian].

Tkachuk, A. F. (2016). Detsentralizatsiia dlia vsikh: vid zahalnoi informatsii do konkretnykh porad [Decentralization for all: from general information to specific advice]. Kyiv: IKTs «Lehalnyi status». 52 [in Ukrainian].

Ukaz Prezydenta Ukrainy №68/2016: «Pro spryiannia rozvytku hromadianskoho suspilstva v Ukraini» vid 26 liutoho 2016 roku. "Stratehiia spryiannia rozvytku hromadianskoho suspilstva v Ukraini». (2016) [Decree of the President of Ukraine №68 / 2016: «On promoting the development of civil society in Ukraine» of February 26, 2016. "Strategy for Promoting the Development of Civil Society in Ukraine»]. Ofitsiine internetpredstavnytstvo Prezydenta Ukrainy. URL: http|lwww.president.gov.ua/documents/ 682016-19805 [in Ukrainian].

Удк [37.013.83:005.336.2]:37.091.12:37.018.46

DOI: https://doi.org/10.35387/od.2(20).2021.133-144

Самко Алла Миколаївна кандидат педагогічних наук, старший науковий співробітник відділу андрагогіки Інституту педагогічної освіти $і$ освіти дорослих імені Івана Зязюна НАПН України
Samko Alla - Candidate of Pedagogical Sciences, Senior Researcher of the Andragogy Department of the Ivan Zyazyun Institute of Pedagogical and Adult Education NAES of Ukraine

ORCID iD: $h$ ttps://orcid.org/0000-0003-0785-0510

E-mail:alla-samko@ukr.net

\title{
ОСОБЛИВОСТІ АНДРАГОГІЧНОЇ КОМПЕТЕНТНОСТІ ПЕДАГОГІЧНОГО ПЕРСОНАЛУ ЗАКЛАДІВ ПІСЛЯДИПЛОМНОЇ ПЕДАГОГІЧНОЇ ОСВІТИ
}

\begin{abstract}
Анотація. В оглядовій статmі проаналізовано особливості профресійної діяльності андрагога в умовах безперервної освіти, охарактеризовано андрагогічну компетентність педагогічного персоналу закладів післядипломної педагогічної освіти. Зазначено, що андрагог, який працює з дорослими, повинен розуміти специфрічні цілі, що стоять перед різними категоріями дорослих-учнів, мотиви їх освітньої діяльності, вміти надавати освітню допомогу та забезпечувати соціально-психологічну підтримку, розвивати рефрлексивні вміння дорослих, вміти діагностувати освітні потреби та можливості дорослих.

На основі аналізу наукових джерел автором виокремлено особливості, що визначають специфріку андрагогічної компетентності
\end{abstract}


педагогічного персоналу закладів післядипломної педагогічної освіти. З'ясовано, що це: диференціація суб'єктів навчального процесу; соціальнопсихологічні особливості; диференційованість та гнучкість профресійної діяльності андрагога; специфіка освітнього середовища; мотиваційна сфера профресійної діяльності педагога.

Зроблено висновок, що визначені особливості андрагогічної компетентності педагогічного персоналу закладів післядипломної педагогічної освіти взаємопов'язані та взаємообумовлені. Зауважено, що профресійна діяльність сучасного фрахівця-андрагога містить сукупність різних інфрормаційних, освітніх, організаційно-управлінських, експертних, соціально-проєктних, дослідницьких та інших ролей $i$ функцій, отже $\epsilon$ дифреренційованою та гнучкою.

Ключові слова: андрагог; специфріка; андрагогічна компетентність; педагогічний персонал; післядипломна педагогічна освіта; освіта дорослих.

Samko Alla

\title{
PECULIARITIES OF ANDRAGOGICAL COMPETENCE OF PEDAGOGICAL STAFF OF POSTGRADUATE PEDAGOGICAL EDUCATION INSTITUTIONS
}

\begin{abstract}
The review article considers the peculiarities of the professional activity of a pedagogue-andragogue in the conditions of continuous education; it characterizes the andragogical competence of the pedagogical staff of postgraduate pedagogical education institutions. It is stated that the andragogue who works with adults should understand the specific goals of different adult students categories, the motives of their educational activities, be able to provide educational assistance and provide socio-psychological support, to develop reflective skills of adults, be able to diagnose adults' educational needs and opportunities.

Based on the analysis of scientific sources, the author highlights the peculiarities that determine the specifics of andragogical competence of the pedagogical staff of postgraduate pedagogical education. It has been found out that they are: differentiation of the subjects of educational process; socio-psychological peculiarities; differentiation and flexibility of the andragogue's professional activity; specifics of the educational environment; motivational sphere of the pedagogue's professional activity.

There is concluded that certain peculiarities of the andragogical competence of the pedagogical staff of postgraduate pedagogical education institutions are interconnected and interdependent. It is noted that the professional activity of the modern andragogue-specialist contains a set of different informational, educational, organizational-managerial, expert, social-project, research and other roles and functions, therefore it is differentiated and flexible.
\end{abstract}

Key words: andragogue; specifics; andragogical competence; pedagogical staff; postgraduate pedagogical education; adult education.

Постановка проблеми, її актуальність. Післядипломна педагогічна освіта як органічна складова системи безперервної освіти спрямована на поглиблення, розширення й оновлення професійних знань, 
умінь і навичок, розвиток професійно важливих якостей фахівців, які здійснюють науково-педагогічну діяльність. Одним із головних напрямів професійного зростання педагога у сфері освіти дорослих $є$ розвиток андрагогічної компетентності, що передбачає зміну стандартних форм і методів роботи з дорослими, спонукаючи до активності, пошуку спільних рішень, прояву свого потенціалу, розвитку професіоналізму. Дослідження проблеми розвитку андрагогічної компетентності педагогічного персоналу української системи освіти дорослих є особливо актуальною.

Аналіз актуальних досліджень і публікацій. Науковий інтерес для дослідження становлять праці вчених про неперервну освіту та підвищення кваліфікації (В. Бондар, Л. Даниленко, Г. Єльникова, А. Кузьмінський, В. Маслов, Н. Ничкало, В. Олійник, Н. Протасова, Л. Пуховська, В. Пуцов, Т. Сущенко, Т.Шамова); теоретичні та методичні основи андрагогіки та професійної підготовки андрагогів (О. Аніщенко, В. Балута, С. Ізбаш, Л. Лук'янова, О. Огієнко, О. Пєхота, Л. Пуховська, М. Скрипник, Т. Сорочан, А. Старєва); проблематику вітчизняної післядипломної педагогічної освіти як складової освіти дорослих (О. Бондарчук, Л. Даниленко, П. Лушина, В. Олійник, Н. Протасова, В. Сидоренко, М. Скрипник, І. Смагін, Т. Сорочан).

Мета статті - висвітлення особливостей, що визначають специфіку андрагогічної компетентності педагогічного персоналу закладів післядипломної педагогічної освіти.

Виклад основного матеріалу дослідження. Постійне збагачення змісту освіти у закладах післядипломної педагогічної освіти із урахуванням сучасних досягнень науки та практики, відносно короткий період навчання слухачів актуалізують посилення вимог до діяльності педагогів, які здійснюють освітній процес із дорослими учнями. Прийняття місії андрагога передбачає оволодіння педагогом відповідних основ діяльності, вибір андрагогічної позиції, освітньої стратегії, визначення масштабу суб'єкта навчання. У цьому особливе значення надається професійному розвитку педагогів і, зокрема, формуванню їх андрагогічної компетентності.

Педагогічний персонал закладів післядипломної освіти, що надають освітні послуги дорослим, мають володіти андрагогічною компетентністю, яка є складником їхнього професіоналізму, що передбачає зміну стандартних форм і методів роботи з дорослими особами, спонукаючи їх до активності, пошуку спільних рішень, прояву інтелектуального й соціокультурного потенціалу через застосування різних форм групової роботи, які віддзеркалюють внутрішні інтереси та потреби всіх учасників освітньої діяльності, а психологічно комфортна обстановка сприяє пошуку нових знань і набуттю професійних компетенцій (Adult leaning professions in Europe..., 2008). Андрагогічна компетентність викладача спонукає до аналізу, осмислення й творчого ставлення до професійної діяльності, сприяє досягненню високого рівня творчості, самореалізації у професійній діяльності.

За С. Толочко (2019, с. 137), андрагог має володіти: 1) системним мисленням, що сприяє цілісному розумінню професійної діяльності, своєї ролі та місця у системі освіти дорослих; 2) навичками аналізу та 
проєктування освітніх програм особистісного і професійного зростання дорослих; 3) здатністю до рефлексивного аналізу якості здійснення організаційної та науково-методичної діяльності; 4) сформованими навичками організації групової роботи, активного, інтерактивного, ситуативного й спеціального навчання слухачів, ефективного педагогічного спілкування з ними, а також методами педагогічного впливу; 5) змістом, сучасними методами, формами навчання дорослих на основі положень андрагогіки; 6) технологіями побудови навчального процесу; 7) способами мотивації слухачів до неперервного навчання та розвитку, конструювання соціально-педагогічних, рольових та ігрових ситуацій, що приводять у дію механізми самоорганізації та саморозвитку, стимулюють до творчої активності.

Нам імпонують такі показники вияву андрагогічної компетентності педагогічного персоналу закладів післядипломної освіти (Семенова, 2020):

- готовність до роботи з дорослими, створення оптимальних умов для навчання дорослих, здійснення методологічно орієнтованої освіти, необхідної для роботи з потоком інформації, що постійно розширюється;

- уміння визначати освітні потреби і запити дорослих, ураховувати особливості їхньої мотивації, процесу навчання, групової динаміки дорослої аудиторії;

- застосовувати технології модерації, фрасилітації, менторства, тьюторства, коучінгу, тренінгу, едвайзингу, супервізорства;

- спроможність визначати цілі, прикінцеві результати навчання, спонукати слухачів до рефлексії, опанування навичок планування, відбору змісту, форм і методів навчання з урахуванням інтересів і соціокультурних потреб, інтелектуальних здібностей та персональних обмежень.

Потрібно зазначити, що за умови недостатньої кількості знань у галузі андрагогіки, наявності незначного досвіду педагогічної діяльності 3 дорослою аудиторією, викладач спочатку шляхом ситуативної самоосвіти намагається вирішити проблему. Надалі в ході формування та розвитку андрагогічної компетентності необхідна систематична самоосвіта, оскільки вона дозволяє повніше реалізувати вибрану викладачем професійноосвітню стратегію. Дослідники (Ross-Gordon, 2001) наголошують, що фахівці, які продовжують своє навчання, тобто займаються самоосвітою як педагоги дорослих, збільшують свій освітній потенціал, професійно розвиваються та зростають. Як наслідок, покращуються й навчальні досягнення їхніх учнів.

У контексті нашого дослідження зміст андрагогічної компетентності педагогічного персоналу закладів післядипломної педагогічної освіти ми розглядаємо з урахуванням специфіки їхньої професійної діяльності - 3 одного боку, як викладача, з іншого, як фахівця, який сам потребує систематичного підвищення професійної компетентності, постійного оновлення знань, насамперед у сфері освіти дорослих. На основі аналізу наукових джерел нами виокремлено особливості, що визначають специфіку андрагогічної компетентності педагогічного персоналу закладів післядипломної педагогічної освіти. Розглянемо їх детальніше.

Передусім потрібно акцентувати увагу на андрагогічній взаємодії 
суб'єктів освітнього процесу. Зазначимо специфіку суб'єктів навчального процесу, що включають дві підгрупи: дорослі - слухачі та дорослі педагоги (організатори навчання). Вони представлені: різними категоріями - це викладачі різноманітних освітніх закладів (інститутів, університетів, академій, державних і приватних вузів); різними галузями знань (гуманітарними, технічними, економічними та ін.); різними віковими категоріями; різними особистісними ціннісними орієнтаціями, звичками, мотивами поведінки; викладачі, що мають неоднаковий науковий (вчений ступінь, звання), посадовий (старші викладачі, доценти, професори) статус роботи та досвід роботи у ВНЗ, інші категорії (Самко, Калюжна, 2021).

У суб'єкт-суб'єктній взаємодії основних учасників навчального процесу головним $€$ врахування андрагогічних принципів партнерства, використання досвіду, орієнтація на дорослого-слухача, врахування вікових та індивідуальних пізнавальних особливостей дорослих-слухачів та дорослих-педагогів (організаторів навчання). Кожна людина $є$ неповторною індивідуальністю, яка має свої уподобання, характер, фрізичні та розумові здібності, освіту, культуру, життєвий та професійний досвід. Зважаючи на це, дорослі-слухачі мають свій індивідуальний стиль навчання, а дорослим-педагогам притаманний свій індивідуальний стиль викладання, i це $€$ фрактори суб'єкт-суб'єктного навчального процесу. Для успішного процесу навчання андрагог повинен вміти визначати стилі навчання дорослих учнів та втілювати їх у свій індивідуальний стиль викладання.

Розглянемо соціально-психологічні особливості навчання дорослих. Отже, дорослі - це особливий контингент слухачів, які мають певний життєвий досвід, професійні знання, вже сформовані погляди на життя, стереотипи професійної діяльності, ціннісні орієнтації, звички, мотиви поведінки та інші особистісні характеристики. Навчання дорослого характеризується прагматичним ставленням до освітніх послуг, включенням освіти у загальний контекст життєдіяльності, залежністю освітнього середовища від їхніх домінуючих інтересів і потреб. Дорослий як суб'єкт навчальної діяльності відрізняється специфічною навчальною мотивацією, він самостійно визначає цілі своєї навчальної діяльності, обирає форми, методи, засоби та способи навчання, самостійно регулює процес засвоєння навчальної інфоормації, оцінює та корегує результати просування, розвиває власний досвід, усвідомлює свої можливості та своє місце в цій діяльності.

Саме тому основними психологічними особливостями навчання дорослих будуть такі: 1) Дорослі вивчатимуть лише те, що, на їхню думку, їм необхідно, їхнє навчання буде ефективним тоді, коли у них з'явиться потужна внутрішня мотивація для оволодіння певними знаннями або для набуття нових навичок. 2) Задля реалізації потреби дорослого слухача у негайному застосуванні одержаних знань, умінь та навичок на заняттях часто використовують рольові ігри, імітацію реальних життєвих ситуацій. 3) Дорослі люди, як правило, навчаються в процесі роботи, тому основна перешкода практичного характеру полягає в тому, що у дорослих, працюючих людей часто не вистачає часу для повноцінних занять 3 викладачем або самостійно. 4) На навчання дорослих людей великий 
вплив має попередній досвід. У дорослих сприйняття знань є пов'язаним, тому знання повинні корелювати з накопиченим життєвим досвідом. Якщо нові знання не узгоджуються з тим, що учень уже знає, він підсвідомо налаштовується на те, щоб такі знання відхилити. 5) Важливо вміти відкинути минулий невдалий досвід вивчення і розпочати все заново. Одним з гальмівних факторів у процесі навчання стає занепокоєння щодо можливих невдач, тому на заняттях важливо створювати неформальну обстановку. 6) Більшість дорослих негативно ставляться до оцінювання їхніх знань. Конкуренція погано впливає на навчання дорослих людей (Цвяк, URL). Більшість з них досить критично ставляться до своєї здатності чогось навчитися; тому психологи стверджують, що дорослих необхідно не оцінювати, а скеровувати. 7) У навчанні дорослих осіб слід застосовувати різноманітні методи навчання.

Далі проаналізуємо характерні особливості професійної діяльності педагогів-андрагогів. Зазначимо, що зміст діяльності андрагога настільки багатофункціональний, багатокомпонентний та багатоплановий, що його можна визначити як «надпрофесійний». Специфіка діяльності андрагога вимагає міждисциплінарного підходу при визначенні змісту освіти для групи дорослих учнів, а також використання системи форм і методів навчання із ураховуванням вікових, професійних, особистісних та інших особливостей слухачів.

Андрагогічна компетентність педагогічного персоналу містить ряд загальнокультурних і професійних компетентностей: загальних і спеціальних, в залежності від соціального запиту і конкретних освітніх потреб дорослих учнів. Наголосимо на особливостях професійної діяльності андрагогів, в яких вони повинні володіти певними особистісними якостями, знаннями та вміннями, реалізуючи всі види професійної діяльності (викладацька, організаторська, науково-дослідницька, управлінська, рефлексивна) та професійні ролі (консультант, тьютор, модератор, менеджер, фасилітатор та ін.).

Аналіз наукового доробку відомої української дослідниці Л. Лук'янової (2013, с. 259-260) показує, що ролі андрагога можуть змінюватися залежно від виховних і навчальних завдань. Вибір однієї 3 професійних позицій (ролей) вимагає від андрагога відповідних професійних функцій і рис. За Л. Лук'яновою (2013), йдеться про такі інтегрально-рольові позиції андрагога, як: учитель - медіатор знань; гід; фасилітатор; тренер; носій культури тощо, що уособлює виконання різних соціальних ролей. Андрагог виступає в ролі вчителя, лідера, спонсора, керівника, представника навчального закладу, зразка для інших. Іншими словами ефективний педагог для дорослих має «носити безліч капелюхів» упродовж навчального процесу (Galbraith, Shedd, 1990, p. 9). Серед основних «капелюхів» (професійних ролей) вчителя дорослих основними можна вважати роль тьютора (того, хто забезпечує супровід індивідуальних освітніх програм у системі підвищення кваліфікації); модератора (того, хто виконує функції консультанта упродовж навчального процесу). Проте, безсумнівно, провідною для андрагога $\epsilon$ роль фасилітатора, яка допомагає дорослим учням осмислювати здобуті знання 
та правильно їх застосовувати. Андрагог-фасилітатор створює сприятливе навчальне середовище; використовує принципи навчання дорослих у плануванні часу та способу навчатися (тобто як і коли); заохочує дорослих учнів формулювати власні цілі навчання та обирати й використовувати різні ресурси для досягнення своїх цілей; допомагає дорослим учням оцінювати власні навчальні результати (Brookfield, 1986).

Зауважимо, що керуючи процесом навчання, андрагог визначає форми взаємодії учасників, і повинен бути готовим до зміни своїх ролей та виконуваних завдань, удосконалювати андрагогічну компетентність. Таким чином, ролі викладача (андрагога) при навчанні дорослих у системі післядипломної освіти відображають гуманістичну сутність його діяльності, забезпечують високу внутрішню мотивацію, спрямованість на створення належних умов для постійної самоосвіти та самовдосконалення.

Наступною характерною особливістю $€$ специфіка освітнього процесу, що здійснюється в післядипломний період. Підвищення кваліфікації фахівців відбувається на андрагогічних засадах із урахуванням особливостей навчання дорослих: пріоритету самостійного навчання; спільної діяльності; опори на досвід слухачів; індивідуалізації, системності, контекстності навчання; актуалізації результатів навчання; елективності навчання; розвитку освітніх потреб; усвідомленості навчання.

Дослідники (Семиченко, \& Хлєбнікова, 2002) підкреслюють особистісну зорієнтованість навчання в системі післядипломної освіти. Йдеться про «... виявлення побажань, інтересів, очікувань, досвіду слухачів з метою індивідуалізації роботи з ними, забезпечення певного балансу особистісної компетентності й сучасних вимог до професіонала, до культури самостійної діяльності; розробки технології, орієнтованої на вимоги практики і вже набутий досвід слухачів; а також виявлення досягнутого результату, тобто зміну у потребах, інтересах, мотивації, знаннях і вміннях індивіда».

Для якісної організації та здійснення навчального процесу 3 дорослими необхідно враховувати такі особливості його побудови: психологічний клімат, використання активних методів навчання як способу підвищення пізнавальної активності слухачів (Кутик \& Жадан, URL), їх залученість В освітній процес, створення атмосфери проблемного обговорення актуальних завдань, спрямованість на прикладні (неакадемічні), особистісно-значущі й проблемно викладені знання тощо.

Перелічені особливості навчання дозволяють організувати процес безперервного підвищення кваліфікації педагогічних кадрів відповідно до їх потреб і життєвого досвіду, що узгоджується з принципами навчання дорослих, які виокремлює М. Ноулз (2005): навчання дорослих має бути проблемно орієнтоване, спиратися на їхній досвід і досвід, отриманий у результаті навчання, має бути значущим для того, хто навчається; цілі навчання повинні бути сформульовані за участю тих, хто навчається; той, хто навчається, повинен отримувати зворотний зв'язок про досягнутий прогрес стосовно цілей.

Особливої уваги потребує мотиваційна сфера педагогічного 
персоналу закладів післядипломної педагогічної освіти. Вагомий науковий доробок вчених (Додонов, 1984; Маркова, 1996; Панченко, 2018; Smith, 1983) вказує на те, що мотивація - це сукупність зовнішніх та внутрішніх факторів, які забезпечують спонукання працівника до цілеспрямованої діяльності. Б. Додонов (1984) виокремлює такі структурні компоненти мотивації: задоволення від самої діяльності; значущості для особистості безпосереднього її результату; «мотивуючої» сили винагороди за діяльність; тиску, що примушує особистість до певних дій.

Слід зауважити, що недостатня мотивація стає обмежувальним чинником, який не дає змоги педагогові втілити свої потенційні можливості. У ширшому контексті мотивацію можна розглядати як комплексну систему, що складається з мотивів особистості та дій, спрямованих на активізацію цих мотивів. Однак до складу мотивації входять не лише мотиви та дії щодо їх реалізації, а також і ситуативні чинники (вплив колег, родинне оточення, специфріка педагогічної діяльності, навчального закладу тощо).

3 огляду на цілі, якими керується андрагог у професійній діяльності, можна виокремити три основні вектори мотивації: спрямованість на себе (передбачає самореалізацію та самоствердження педагога як основну мету); спрямованість на інших (пріоритетним завданням $€$ забезпечення комфортних умов для оточуючих, наприклад учнів); спрямованість на завдання (рушійною силою постає реалізація поставленого завдання) (Особистість у сучасній психології, URL). Останній напрямок передбачає розгалуження на результат (досягнення кінцевої мети) та процес роботи (особлива увага звертається на способи та методи виконання роботи, а не на ії підсумок). Якщо говорити про скерованість на результат роботи, то варто зазначити, що вона також має два напрямки, направлені на досягнення успіху й уникнення невдач.

Мотивація діяльності педагога уособлює різні види спонукань: власне мотиви, потреби, інтереси, прагнення, цілі, установки, ідеали (Кутик $\&$ Жадан, URL). Домінуючими мотивами $€$ широкі пізнавальні мотиви (орієнтація на отримання додаткових знань, отримання задоволення від набуття нових знань або інформації), внутрішні соціальні мотиви (наявність потреби в самореалізації, особистому зростанні), зовнішні соціальні мотиви (бажання підвищення кваліфікаційного рівня, отримання педагогічного звання, бажання кар'єрного зростання, отримання визнання з боку колег). Саме мотивація педагогів впливає на їх професіоналізм, продуктивність та ефективність педагогічної діяльності. Дослідники (Панченко, 2018) називають такі мотиваційні чинники педагога-андрагога: підвищення свого фрахового рівня, прагнення працювати по-новому, оволодіння сучасними технологіями навчання й виховання, бажання змінити свій статус, зробити кар'єру, підвищити рівень майстерності, ознайомитися з перспективним досвідом роботи, сподівання на продуктивне спілкування з колегами тощо.

Як слушно зауважує А. Маркова (1996), мотивація, професійне мислення, рівень домагань, задоволеність працею, психологічна ціна досягнутих результатів які присутні у професійній діяльності педагога, впливають на його професіоналізм, продуктивність та ефеективність 
педагогічної діяльності. Мотивація підвищення професійної кваліфікації педагогів як одна з форм самоактуалізації особистості найбільше пов'язана 3 психічним здоров'ям педагогів, рівнем задоволення роботою та оволодінням засобами вдосконалення профресійної кваліфікації (самовизначення, саморозвиток, самовираження). Для високовмотивованих педагогів, порівняно з низько мотивованими, має місце статистично значущий вищий рівень задоволення потреб особистісного розвитку, захоплення роботою, вмотивованості праці, використання власного досвіду, задоволення трудовою діяльністю.

Висновки і перспективи подальших досліджень. Узагальнення результатів наукового пошуку дають підстави для таких висновків. У професійній діяльності андрагог має враховувати вікові, психологічні, соціальні, професійні особливості (як свої, так і дорослих-учнів); використовувати досвід під час навчання (як свій, так і дорослих-учнів); визначати освітні потреби, мету навчання та шляхи її досягнення; сприяти створенню умов, необхідних для самореалізації людини, підвищення ефективності та результативності її життєдіяльності.

Педагогічний, науково-педагогічний працівник закладу післядипломної педагогічної освіти виступає одночасно у двох ролях: як викладач і як фахівець, який сам потребує систематичного підвищення професійної компетентності, постійного оновлення знань, і насамперед у сфрері освіти дорослих, тому розглянуті нами особливості взаємопов'язані та взаємообумовлені. Це диференціація суб'єктів навчального процесу (вік, фрах, рівень освіти, освітні запити, гендерні особливості тощо); соціальнопсихологічні особливості (вже сформовані погляди на життя, стереотипи професійної діяльності, ціннісні орієнтації, звички, мотиви поведінки та інші особистісні характеристики); диференційованість та гнучкість професійної діяльності сучасного фахівця-андрагога (сукупність різних інфоормаційних, освітніх, організаційно-управлінських, експертних, соціально-проєктних, дослідницьких та інших ролей і функцій); специфріка освітнього середовища (особистісно-орієнтований характер освітнього процесу, що здійснюється в післядипломний період, від якого залежать фрункціонально-посадові обов'язки андрагога); особливості мотивації професійного розвитку педагогічного персоналу (варіативність та індивідуальна зорієнтованість).

Проведена робота не вичерпує усіх аспектів досліджуваної проблеми. Перспективу подальшого наукового дослідження вбачаємо у виявленні тенденцій розвитку андрагогічної компетентності педагогів закладів післядипломної педагогічної освіти.

\section{Список використаних джерел}

Додонов, Б.И. (1984). Структура и динамика мотивов деятельности. Вопросы психологии. 4. 126-130.

Кутик, О. \& Жадан, Р. Навчання педагога протягом життя: мотиваційна складова. URL: https://ru.calameo.com/read/00313072025c3c0aa33ca

Лук'янова, Л.Б. (2013). Зміст інтегрально-рольової позиції педагога-андрагога у зарубіжній науковій думці. Освіта дорослих: теорія, досвід, 
перспективи. 7. 257-266.

Маркова, А.К. (1996). Психология профессионализма. М.: Международный гуманитарный фонд «Знание». 312.

Особистість у сучасній психології. Психологічна характеристика. URL: https://osvita.ua/vnz/reports/psychology/10026/

Панченко, С.М. (2018). Нові можливості та механізми післядипломної освіти педагога: контекст Закону України «Про освіту». Освіта Сумщини. 2 (38). 2-7.

Самко, А.М. \& Калюжна, Т.Г. (2021). Андрагогічні засади освітнього процесу в системі післядипломної педагогічної освіти. Розвиток освітніх систем в умовах євроінтеграційних трансформацій: зб. матеріалів Міжнародної науково-практичної конференції, ЧНУ імені Ю. Федьковича. 270-275.

Семенова, О. (2020). Андрагогічна компетентність як необхідний складник професіоналізму науково-педагогічного персоналу закладу вищої освіти. Актуальні питання гуманітарних наук. 33, т. 2. 307-312.

Семиченко, В. А. (2002). Актуальні проблеми реформування системи післядипломної освіти в Україні. Післядипломна освіта в Україні. 2. 56-60.

Толочко, С.В. (2019). Теоретичні й методичні засади фрормування науковометодичної компетентності викладачів у системі післядипломної освіти: дис. ... д-ра пед. н. Київ. 451.

Цвяк, Л.В. (2014). Психолого-педагогічні умови ефективного навчання дорослих іноземної мови. URL: http://nbuv.gov.ua/UJRN/Nvuuped_2014_30_66

Adult leaning professions in Europe, a study on current situation, trends and issues: Research voor Beleid: final report. (2008). Brussels: European Commission.

Brookfield, S. (1986). Understanding and Facilitating Adult Learning: A comprehensive analysis of principles and effective practices. SanFrancisco, CA.: Jossey-Bass. 400.

Galbraith, M.W., Shedd, P.E. (1990). Building skills and proficiencies of the community college instructor of adult learners. Community College Review. 18 (2). 6-14.

Knowles, M. (2005). The adult learner: The definitive classic in adult education and human resource development (6th ed.). Burlington, MA: Elsevier. 342.

Ross-Gordon, J. (2001). Contemporary viewpoints on teaching adults effectively. San-Francisco, CA: Jossey-Bass. 127.

Smith, R.M. (1983). Leaming How to Leam. Applied Theory for Adults. Milton Keynes. 37.

\section{References (translated and transliterated)}

Dodonov, B.I. (1984). Struktura i dinamika motivov deyatel'nosti [Structure and dynamics of motives of activity]. Voprosy psikhologii - Questions of psychology. 4. 126-130 [in Russian].

Kutyk, O., Zhadan R. Navchannya pedahoha protyahom zhyttya: motyvatsiyna skladova [Teacher training during life: motivational component]. URL: https://ru.calameo.com/read/00313072025c3c0aa33ca [in Ukrainian].

Luk"yanova, L.B. (2013). Zmist intehral'no-rol'ovoyi pozytsiyi pedahoha-andrahoha u zarubizhniy naukoviy dumtsi [The content of the integral-role position of the teacher-andragogue in foreign scientific thought]. Osvita doroslykh: teoriya, 
dosvid, perspektyvy - Adult education: theory, experience, prospects. 7. 257-266 [in Ukrainian].

Markova, A.K. (1996). Psikhologiya professionalizma [Psychology of professionalism]. Mezhdunarodnyy gumanitarnyy fond «Znaniye» International Humanitarian Foundation «Knowledge», M., 312 [in Russian].

Osobystist' u suchasniy psykholohiyi. Psykholohichna kharakterystyka [Personality in modern psychology. Psychological characteristics]. URL: https://osvita.ua/vnz/reports/psychology/10026/ [in Ukrainian].

Panchenko, S.M. (2018). Novi mozhlyvosti ta mekhanizmy pislyadyplomnoyi osvity pedahoha: kontekst Zakonu Ukrayiny «Pro osvitu» [New opportunities and mechanisms of postgraduate teacher education: the context of the Law of Ukraine «On Education»]. Osvita Sumshchyny - Education of Sumy region. 2 (38). 2-7 [in Ukrainian].

Samko, A.M., Kalyuzhna, T.H. (2021). Andrahohichni zasady osvitn'oho protsesu v systemi pislyadyplomnoyi pedahohichnoyi osvity [Andragogical principles of the educational process in the system of postgraduate pedagogical education]. Rozvytok osvitnikh system $v$ umovakh yevrointehratsiynykh transformatsiy - Development of educational systems in the conditions of European integration transformations: zb. materialiv Mizhnarodnoyi naukovo-praktychnoyi konferentsiyi, CHNU imeni YU. Fed'kovycha, 270275 [in Ukrainian].

Semenova, O. (2020). Andrahohichna kompetentnist' yak neobkhidnyy skladnyk profesionalizmu naukovo-pedahohichnoho personalu zakladu vyshchoyi osvity [Andragogical competence as a necessary component of professionalism of scientific and pedagogical staff of higher education institution]. Aktual'ni pytannya humanitarnykh nauk - Current issues of the humanities. Vyp. 33, t. 2. S. 307-312 [in Ukrainian].

Semychenko, V.A. (2002). Aktual'ni problemy reformuvannya systemy pislyadyplomnoyi osvity $v$ Ukrayini [Actual problems of reforming the system of postgraduate education in Ukraine]. Pislyadyplomna osvita $v$ Ukrayini - Postgraduate education in Ukraine. 2. 56-60 [in Ukrainian].

Tolochko, S.V. (2019). Teoretychni y metodychni zasady formuvannya naukovometodychnoyi kompetentnosti vykladachiv u systemi pislyadyplomnoyi osvity: dys. ... d-ra ped. $n$. [Theoretical and methodical bases of formation of scientific and methodical competence of teachers in system of postgraduate education]. Kyyiv, 451 [in Ukrainian].

Tsvyak, L.V. (2014). Psykholoho-pedahohichni umovy efektyvnoho navchannya doroslykh inozemnoyi movy [Psychological and pedagogical conditions for effective adult language learning]. URL: http://nbuv.gov.ua/UJRN/Nvuuped_2014_30_66 [in Ukrainian].

Adult leaning professions in Europe, a study on current situation, trends and issues: Research voor Beleid: final report. Brussels: European Commission, 2008. 157 [in English].

Brookfield, S. (1986). Understanding and Facilitating Adult Learning: A comprehensive analysis of principles and effective practices. SanFrancisco, CA.: Jossey-Bass. 400 [in English].

Galbraith, M. W., \& Shedd, P. E. (1990). Building skills and proficiencies of the community college instructor of adult learners. Community College Review. 18 (2), 6-14 [in English]. 
Knowles, M. (2005). The adult learner: The definitive classic in adult education and human resource development (6th ed.). Burlington, MA: Elsevier. 342. [in English].

Ross-Gordon, J. (2001). Contemporary viewpoints on teaching adults effectively. San-Francisco, CA: Jossey-Bass. 127. [in English].

Smith, R. M. (1983). Leaming How to Leam. Applied Theory for Adults. Milton Keynes. 37 [in English].

УДК 355.232

DOI: https://doi.org/10.35387/od.2(20).2021.144-152

Троцький Руслан Сергійович кандидат педагогічних наук, начальник кафеедри тактикоспеціальної підготовки Київського інституту Національної гвардії України
Trotskyi Ruslan - Candidate of Pedagogical Sciences, Head of the Department of Tactical and Special Training of the Kyiv Institute of National Guard of Ukraine

ORCID iD: https://orcid.org/0000-0002-9734-279X???

E-mail:rus197829@ukr.net

$\begin{array}{lr}\text { Манжос } & \text { Олексій } \\ \text { Олександрович } & \text { старший } \\ \text { викладач } & \text { кафредри } \\ \text { загальновійськових } & \text { дисциплін, } \\ \text { начальник служби екологічної } \\ \text { безпеки Київського інституту } \\ \text { Національної гвардії України }\end{array}$

ORCID iD: https://orcid.org/0000-0002-9729-1703

E-mail:moo2021@gmail.com

\section{УДОСКОНАЛЕННЯ ЗМІСТУ ФАХОВОЇ ПІДГОТОВКИ МАЙБУТНІХ ОФІЦЕРІВ У ВИЩИХ ВІЙСЬКОВИХ НАВЧАЛЬНИХ ЗАКЛАДАХ В УКРАЇНІ}

Анотація. В оглядовій статті проаналізовано особливості фрахової підготовки майбутніх офріцерів у вищих навчальних закладах MBC України. Акцентовано увагу на необхідності вдосконалення змісту фрахових дисциплін шляхом збагачення тематики навчальних $і$ робочих програм, розроблення проблемних змістових модулів, лекцій, практичних і семінарських занять, програм ознайомчої практики і стажування; використання інтерактивних форм пізнавальної діяльності (лекція-дискусія, бінарна лекція, рольові ігри, проведення відеолекторіїв), організація виховних заходів (зустрічі з військовослужбовцями, керівним складом); проведення тренінгів (комунікативних, з педагогічної майстерності); використання різноманітних методів (проектів, мозкового итурму, дискусія, профессійно орієнтовані ситуації, практикуми та ін.); організація семінарів для викладачів фрахових дисциплін з проблем досвіду 